\title{
Insights in the Job, Skill and Wage Structure of the Netherlands: 1986-98*
}

\author{
Bas ter Weel \\ Maastricht Economic Research Institute on Innovation and Technology (MERIT) \\ Maastricht University \\ P. O. Box 616, $6200 \mathrm{MD}$, Maastricht \\ The Netherlands \\ b.terweel@merit.unimaas.nl \\ http://meritbbs.unimaas.nl/staff/bas/terweel.html
}

\begin{abstract}
Summary
The increase in the supply of relatively high-skilled workers since the 1960's, recently accompanied by rapid technical change as a result of the introduction of new ICT's, has increased the demand for high-skilled labour dramatically. In many countries this has led to a dramatic increase in the skilled workers wage premium. However, in the Netherlands wage dispersion is hardly observed. This paper shows why wages have been relatively stable in the Netherlands. Empirical analysis of a unique data set reveals that the increase in the demand for skills has been captured by a more efficient assignment of workers to jobs, not by increasing wage premiums.
\end{abstract}

Keywords: wage level and structure, income distribution JEL classification: J31, O15

* I want to thank Allard Bruinshoofd for excellent research assistance. Daron Acemoglu, Lex Borghans, Hugo Hollanders, Joan Muysken, Erik de Regt, Luc Soete and Coen Teulings provided detailed and helpful comments on an earlier draft of this paper. Seminar participants at MERIT are also acknowledged. The Research Centre for Education and the Labour Market (ROA) and the Organisatie voor Strategisch Arbeidsmarktonderzoek (OSA), particularly Piet Allaart, are acknowledged for providing the data utilised in this paper. Finally, I acknowledge Netherlands Organization for Scientific Research (NWO) support. Of course, the usual disclaimer applies. 


\section{Introduction}

Douglas (1926) and Tinbergen (1975) have identified the evolution of the wage structure or the distribution of wages as a race between technical development and access to education. These observations have gained renewed attention over the last few years in the debate and literature on skill-biased technical change (SBTC). According to this strand of literature, new technologies are by their nature complementary to skills. This suggests that there has always been some SBTC, as a result of capital-skill complementarity (Griliches, 1969 and Goldin and Katz, 1998), but the rapid introduction of new technologies, such as computers and Information and Communication Technologies (ICT's), has recently led to an acceleration in SBTC. In this regard, Autor, Katz and Krueger (1998) find for the United States that in the 1970's college graduates earned 55 percent more than high school graduates. The premium fell to 41 percent in 1980, but then increased to 62 percent in 1995; and Machin and Van Reenen (1998) present international evidence in favour of the SBTC hypothesis for the period $1975-89 .^{1}$

However, as Berman, Bound and Griliches (1994) point out, the increased wage differentials - particularly in the United Kingdom and the United States - have been well-documented but there is no consensus as to its causes. They argue that part of the widening of the educational differential can be attributed to a slowdown in the rate of growth of the skilled population accompanied by continued growth in the demand for skilled labour, but the source of this growth in demand remains unexplained.

To improve the understanding of SBTC Acemoglu (1998) argues that new technologies are not complementary to skills by nature but by design. In his approach he establishes that when the direction of technical change is endogenous, it can be shown that the demand for skills and its wage premium first falls and then increases

\footnotetext{
${ }^{1}$ See Sanders and Ter Weel (1999) and Chennells and Van Reenen (2000) for overviews of more than 100 studies dealing with the phenomenon of SBTC.
} 
sharply, following the large increase in the supply of skills, which is in line with the obsevations of Autor, Katz and Krueger (1998) for the United States.

Motivated by this reasoning, this paper develops similar arguments in an analysis of the evolution of wages in the Netherlands over the past two decades. ${ }^{2}$ Gottschalk (1997) observes that in the Netherlands the supply of skilled labour has increased since the 1960's, but the returns to education have declined strongly and are only recovering gradually, whereas attainment and investment levels among workers have remained high. While some caution with this observation is appropriate (Gottschalk does not control for a fall in the legal minimum wage level) he finds that "the relatively small increase in (wage) inequality in the Netherlands reflects a decline in the college (skill) premium, which largely offsets the substantial increase between experience groups and the increase in inequality within groups."

The impact of an increase in the supply of skilled workers on the wage premium is determined by two competing forces. First, it is determined by an ordinary substitution effect, which makes the economy move along a downward sloping relative demand curve. Second, a (endogenous) technology effect shifts the relative demand curve for skilled labour, because the increase in the supply of skilled workers induces faster upgrading of skill-complementary technologies. In Figure 1 the increase in the supply of skilled labour first moves the economy along a short-run (constant

\footnotetext{
2 Many studies deal solely with the United States. On the one hand, this is due to the widely availability of data, like the Current Population Survey and other large panel data sets. On the other hand, the effects of SBTC with respect to the structure of wages seem to be most dramatic in the United States (and the United Kingdom). There have been big burgeons in wage inequality in the United States (and in the United Kingdom), while it is argued that other countries - notably continental European countries - have had a more stable wage structure, mainly as a result of stickiness in the labour market, like unions and other institutions (e.g. Layard, Nickell and Jackman, 1991). In these countries the effects of technical change went through rising unemployment levels (mostly) among unskilled workers: Card, Kramarz and Lemieux (1999) conclude in an analysis of Canada, France and the United States that relative wages for unskilled workers have fallen most in the United States, while unemployment levels went up most in France and to a lesser extent in Canada. Katz, Loveman and Blanchflower (1995) find that the more severe increases in the skill differential in the United Kingdom and the United States in comparison with Japan can be attributed to an acceleration in the rate of growth of the demand for more skilled workers. Evidence for France suggests that the high minimum wage and the ability of French unions to extend contracts in te face of declining membership has somewhat offset the changes in wages in favour of the skilled workers.
} 
technology) relative demand curve from point $\mathrm{A}$ to point $\mathrm{B}$, reducing the skill premium. Then, as Acemoglu (1998) also argues, this relative supply change increases the size of the market for technologies complementary to skills, and induces changes in the direction of technical change towards the availability or abundance of skilled workers, which shifts the relative demand curve in Figure 1 to point $\mathrm{C}$.

The mechanism underlying Figure 1 is simple. Suppose first that the substitution effect dominates the technology effect. As a result, the skill premium falls. This is a plausible result because an increase in the supply of skilled workers cannot be immediately matched by an equivalent increase in jobs for such workers. Hence, skilled workers will first be matched to jobs below their skill level. Such observations, of increased education without increasing wages, may indicate overinvestment in education and skills in the Netherlands. ${ }^{3}$ Freeman (1976) and Rumberger (1981) examined this issue thoroughly in the United States for the 1960's and Sicherman (1991) for the 1980's. They describe falling (net) returns to investment in human capital and conclude that overeducation has led to crowding out of skills, which is in line with the observations of Autor, Katz and Krueger (1998) for the 1980 's. For the Netherlands such findings are supported by numerous studies on the recently relatively low returns to education (e.g. Hartog and Oosterbeek, 1988 and Hartog, 1999 for an overview).

Now if the technical change effect is strong enough, the skill premium will eventually rise. This is the ABC-case drawn in Figure 1 and offers an explanation for the changes in the college premium in the United States over the past 3 decades (e.g. Katz and Murphy, 1992, Juhn, Murphy and Pierce, 1993 and Acemoglu, 1999).

\section{[INSERT FIGURE 1 OVER HERE]}

\footnotetext{
${ }^{3}$ Another argument for relatively stable wages since the late 1960's is given by Van der Wiel (1999). He finds that Dutch wage formation is dominated by wage leading sectors. The wages in these sectors mainly depend on macroeconomic developments instead of sectoral-specific conditions, especially in the event of an economic upturn. These findings are also valid after 1982, a period with more decentralised wage formation. In addition, Dutch inter-industry wage differentials appear to be noticeably small compared to other (OECD) countries.
} 
However, empirical evidence suggests that the increase in the supply of skilled workers has not led to an increase in the skilled workers wage premium in the Netherlands as observed in the United States. In terms of Figure 1 it could be argued that the technology effect does not dominate to the extent it does in the United States ( $\mathrm{ABC}$ versus $\mathrm{AB} \mathrm{C}^{\prime}$ ). Hence, the premium for skilled labour has not increased as dramatic as in the United States. Several explanations for this observation can be given.

First, it has been argued that although technology can account for a significant part of rising wage dispersion, other factors play a role too. Allen (1996), investigating the United States, and Machin and Van Reenen (1998), in an empirical investigation of seven OECD countries, suggest that technical change alone can only account for a third or less of the changes in wage shares. Hence, the long-run relative demand for skilled labour in Figure 1 is less steep when the shift in relative demand for skilled labour due to technical change is increasing to a lesser extent. As a result, the long-run skill premium may not be at a point such as point $\mathrm{C}$ in Figure 1, but at a lower point like point C'.

Second, labour supply changes, which distribution has changed continuously as a result of the increase in educational attainment, may affect the structure of the wage distribution differently in the Netherlands. The relatively high returns to education in the United States compared to the Netherlands may reflect some relative supply problem in the United States which leads to wage dispersion. Such an argument has been made by Murphy, Riddell and Romer (1998) in a comparative study of Canada and the United States. They find that in the 1980's governmental post-secondary educational programmes in Canada have resulted in only a modest wage differential relative to the United States, where such programmes were not implemented. These findings suggest that demand and supply have been better matched in Canada than in the United States. ${ }^{4}$ A larger increase in the supply of

\footnotetext{
${ }^{4}$ Lloyd-Ellis (1999) finds that in the period 1970-90 students who went to university in the United States saw a decline in the growth rate of academic achievement at all years of schooling, which started to become a serious problem by the mid-1970's; from the 1990's on academic achievement
} 
skilled workers reduces the skilled wage premium in the short run more than is drawn in Figure 1. If the skill premium is below point B, say at point B', in Figure 1, it is of course more difficult or it takes longer to reach a skill premium as high as point $\mathrm{C}^{5}{ }^{5}$

To examine the above empirically, I analyse the Dutch economy along the lines of the OSA database. This database consists of a representative number of workers from 13 sectors over the period 1986-98. I try to structure the labour market and take into account labour demand and supply changes simultaneously. Considering demand and supply changes simultaneously results in a market equilibrium which can be identified by a continuously changing mapping of skills assigned to jobs and consequently to a continuously changing wage rate.

The remainder of this paper is organized as follows. In Section 2 some preliminary results are discussed. Section 3 presents the estimation results. Section 4 concludes.

goes up again. Indeed, Juhn, Murphy and Pierce (1993) present evidence of SBTC in the period 1973-1989. Recent evidence brought together by Murphy and Welch (1999) reveals that since the mid-1990's the growth of the wage premium for skilled workers slowed down, which is in line with the observations of Lloyd-Ellis.

${ }^{5}$ Kiley (1999) considers an alternative approach to get an understanding of SBTC. He builds an expanding varieties framework and shows that an increase in the supply of skilled labour creates SBTC and increases inequality. Krusell, Ohanian, Ríos-Rull and Violante (1997) consider a model of capital-skill complementarity and argue that SBTC simply reflects the rapid growth of the stock of capital combined with the different ways that equipment interacts with skilled and unskilled labour in the production technology. However, they do not address the question whether this is due to the increase in the supply of skilled labour or an (exogenous) increase in the capital stock. 


\section{Data and Some Facts and Figures}

The data I utilise in this paper are drawn from seven surveys conducted by the Organisatie voor Strategisch Arbeidsmarktonderzoek (OSA) from 1986 to 1998 among a relatively small number of individuals. For the seven biannual years respectively 2,325 (1986), 2,279 (1988), 2,352 (1990), 2,399 (1992), 2,531 (1994), 2,654 (1996) and 2,896 (1998) usable observations are available (total number of usable observations: 17,436). Participating individuals were asked several dozens of questions on their labour market position to sketch a clear picture of the Dutch labour market. The analysis here uses only information from a limited number of questions on both demand and supply side characteristics.

I have only included employees and have left self-employed individuals aside because of the unreliable and erratic information for the relevant variables. The same argument holds for the below $2^{\text {nd }}$ and above $98^{\text {th }}$ percentile of the wage distribution.

Other comparable studies documenting the Dutch labour market in this respect are rather scarce, mainly due to data limitations. Draper and Manders (1997) - using a data set which contains educational levels for the period 1969-93 - have shown that labour-saving technical change explains most of the change in the wage structure. Less recent studies, which have reached similar conclusions, are performed by Broer and Jansen (1989) and Hebbink (1991). Broer and Jansen divided the labour force into three categories and focussed on employment, education and productivity and found that higher levels of education have a significant influence on productivity growth in the 1970's and 1980's. Hebbink has also considered three types of labour and found that skilled labour and capital are complements, but that employment of unskilled labour has been worsened by a reduction in the price of capital. ${ }^{6}$

To get an understanding of the data, consider first Figure 2. Figure 2 graphs the median, $10^{\text {th }}$ and $90^{\text {th }}$ percentile of the real $\log$ hourly wage distribution of the data

\footnotetext{
${ }^{6}$ Other related studies are performed by Hartog and Oosterbeek (1988), Oosterbeek (1990) and Hartog, Oosterbeek and Teulings (1993). The latter examines also the effects of aging on wages in the Netherlands.
} 
set for 1986-98. For ease of comparison the figures are indexed to 100 in 1986 for all three series. The overall picture from this figure is that log hourly wages have steadily risen over the whole period. I do not observe, like in the United Kingdom and United States, an acceleration of log hourly earnings in the 1980's and 1990's of the above median wage workers. The median wage series show an almost 15 percent increase in wages for the median worker during the period 1986-98. The pattern of this series is quite linear and shows a steadily increase in the log hourly wage. For the $90^{\text {th }}$ percentile of the wage distribution, the log hourly wage rose relatively fast until 1992 (more than 11 percent), while after 1992 the wage increase was far more modest. The increase in the wage series of the $90^{\text {th }}$ percentile worker is, over the sample period as a whole, comparable to the wage increase of the median worker. As is clear from the figure, the story is significantly different for the $10^{\text {th }}$ percentile of the wage distribution. Since the partially abandoning of the legal minimum wage in the early 1990 's, the wages at the bottom part of the labour market have increased only slightly. The wage of the $10^{\text {th }}$ percentile worker only went up by some 4 percent in the period 1990-98, whereas wages of the median and $90^{\text {th }}$ percentile worker went up 11 by 7 and percent, respectively.

\section{[INSERT FIGURE 2 OVER HERE]}

I communicate the evolution of the log hourly wage for the degree of wage inequality in Figure 3. Wage inequality is simply measured by the log hourly wage differential between the highest ten percent and the lowest ten percent of the wage distribution and the deviation from the median earners: $90^{\text {th }}-10^{\text {th }}, 90^{\text {th }}-50^{\text {th }}$ and $50^{\text {th }}$ - $10^{\text {th }}$. The degree of wage inequality between the $90^{\text {th }}$ and $10^{\text {th }}$ percentile of the wage distribution is increasing rapidly in 1988 and 1990 to some 30 percent. Thereafter, the wage gap remains relatively stable, which may exhibit the effects of the consensus policies between labour unions and employer's organizations. This consensus resulted in wage moderation and better conditions for the median skilled and hence in some narrowing wage distribution since the late 1980's. Indeed, the difference between the 
$90^{\text {th }}$ and $50^{\text {th }}$ percentile is first increasing rapidly but in the 1990 's the wage differential is falling. The overall increase in wage inequality between these two groups is slightly above 16 percent. The difference between the $50^{\text {th }}$ and the $10^{\text {th }}$ percentile increased by more than 50 percent from 1986-98.

\section{[INSERT FIGURE 3 OVER HERE]}

Regardless of the valuable information Figure 2 and 3 contain, the overall picture might be sketched too simple, for the figures do not distinguish personal characteristics, job effects and sector specific properties, i.e. demand and supply characteristics. In the next section the data are explored to show what the underlying phenomena to the wage structure are by focussing on both the demand and supply side of the labour market. 


\section{Wages in the Netherlands}

Table 1 summarizes some important results for each biannual year between 1986 and 1998. Panel A, B and C report the results of simple ordinary least squares (OLS) regressions on log hourly wages. In the first panel only labour supply characteristics are taken into account; Panel B measures only labour demand characteristics and Panel C includes only sector specific characteristics. The supply side characteristics are personal characteristics like level of education, age, race, sex and marital status. Demand side characteristics include job characteristics like job level, firm size and leadership. The variable in Panel $\mathrm{C}$ investigates whether some sectors pay higher wages than others.

The most important results concerning personal characteristics are that age has its usual positive effect on log hourly wages, which is likely to be the result of the presence of seniority payment schemes and the fact that, in general, workers who are most experienced occupy the highest paid jobs. However, the wage premium resulting from such schemes is subject to diminishing returns since the $\operatorname{age}^{2} / 100$ coefficient is negative and significant. The final row of Panel A shows that each year of additional education yields a return between 4 and 6 percent (except for 1986: 2.9\%). The level of education is measured in five categories each containing some standard years of education: 12 for the lowest level (i.e. 8 years of primary education and 4 years of secondary education) and 22 for the highest level of education; the intermediate levels contain 16, 18 and 20 years of education, respectively. Discrimination on race does not seem to be present significantly. Discrimination with respect to sex seems to be severe (between 6.9 and 17.3 percent), but when controlling for the jobs women occupy (mainly low-skilled jobs) discrimination on sex is less severe. Finally, if an employee is married a wage premium between .4 and 6.4 percent is obtained. ${ }^{7}$ The level of significance of the regressions is measured by the adjusted $\mathrm{R}^{2}$ statistic. This

\footnotetext{
${ }^{7}$ Some caution is required here because investigating the cross effect of the variable male and married a positive coefficient is obtained, whereas a negative coefficient turns up when females are married.
} 
statistic lies for Panel A between .279 (1992) and .499 (1994) which are frequently found values for cross-sectional regressions, particularly when it is noted that only supply side characteristics are taken into account in Panel A. ${ }^{8}$

The demand side of the labour market is taken into account by distinguishing 5 different job levels (elementary, low, medium, high and scientific) which are divided in white-collar and blue-collar jobs (except for elementary jobs). These demand side or job characteristics are aggregated from more than a 1,000 four-digit occupational titles into these 9 categories, according to the 1994 CBS SBI code scheme, which categorises mainly on the basis of an analysis of the type of work done in a particular job. ${ }^{9}$ Panel $\mathrm{B}$ in Table 1 shows that, relative to a low-level blue-collar job, the expected pattern of increasing wages along with increasing job levels is present in all years. However, when the same job level is taken into account for each single year it can be observed that the wage premium of the high and scientific jobs, relative to a low-skilled blue-collar job, drops since the early 1990's. This is in line with the pictures drawn in Figure 2 and 3, where the wage gap between the high-paid and the others is falling; or is at least not rising. The fact that high-level and scientific bluecollar jobs pay a higher wage than comparable white-collar jobs may be the result of a relative decline in the enrollment rate and subsequent scarcity of workers with technical studies. Oosterbeek and Webbink (1997) find that the market share of science and engineering in university education decreased from 35\% in 1960 to $22 \%$ in 1989. This decline in relative high-level blue-collar supply may have led the wage

\footnotetext{
${ }^{8}$ The regression in Panel A of Table 1 could alternatively be run at once with dummies for six of the seven biannual years (one reference year). This is sometimes preferred because as a result of technical progress (and inflation) the intercept might change or shift over time. When 1986 is taken as the year of reference the coefficients (and their standard errors) do not change dramatically: Intercept (.023 (.051)), Age (.068 (.002)), Age $2 / 100$ (-.001 (.000)), Non-Dutch (.007 (.003)), Female $(-.159(.008))$ and Married (.032 (.009)). The year dummies are for $1988(.140(.017)), 1990(.286$ $(.017)), 1992(.352(.018)), 1994(.328(.018)), 1996(.397(.017))$ and $1998(.447(.017))$. The reason why I choose for the analysis as shown in Table 1 is that I explore and use the coefficients of each biannual year in the analysis of Table 2 .

${ }^{9}$ The 1994 CBS SBI code is used for all years. Although other CBS SBI codes are available for years before 1994 I analyse the data with only this SBI code. This is mainly done to obtain consistent comparisons of job levels for all years. A disadvantage may be on the one hand that some jobs have disappeared in the period 1986-94, while on the other hand new jobs have been created since 1994.
} 
premium above the average high-level worker wage premium in Panel B.

It is also tested whether firm size has an impact on log hourly wages. It turns out that larger firms pay higher wages ranging from 1.6 percent in 1988 to 4.1 percent in 1996. The overall picture suggests that over time this effect is increasing. Finally, a proxy of the managerial skills of employees has been made by investigating the wage premium with regard to the number of workers a particular person supervises. The data are divided into six classes: supervising none, 1 to 4 persons, 5 to 9,10 to 19,20 to 49 and over 50. It turns out that a more or less constant wage premium of about 6 to 7 percent exists when a worker is supervising other workers.

The explanatory power of the regressions in Panel B is less than in Panel A. The adjusted $\mathrm{R}^{2}$ is lowest in $1990(.213)$ and highest in $1996(.363)$.

The effects of sector characteristics on log hourly wages in Panel C of Table 1 deliver results that are at first sight not very robust. This is of course due to unobserved heterogeneity between an unknown distribution of workers within these sectors. However, relative to the transport sector, workers in some sectors obtain significantly lower or higher wages throughout the whole sample period.

\section{[INSERT TABLE 1 OVER HERE]}

The information from Table 1 can be used to describe the interaction of labour demand and supply. What is of interest are the wage effects of the high relative supply of skilled workers. In terms of Figure 1, this is the move from point B, the short-run labour market reaction to an increase in the supply of relatively skilled labour, to some new long-run labour market situation, point $\mathrm{C}$. When examining the shift from $\mathrm{B}$ to $\mathrm{C}$, information on the skill premium and the extent of the shift in skills supply is obtained.

To do so, Teulings (1995) and Teulings and Vieira (1999) have developed an 
empirical strategy as to how assign workers to jobs. ${ }^{10}$ In terms of Figure 1, this means that immediately after the shift in relative labour supply, skilled workers are assigned to jobs that require actually less skills (point B). In this state of affairs, skilled workers are overeducated to perform such a job and their capabilities are not fully utilised. This situation seems to be applicable particularly to the Netherlands for a long time now. Many, mainly Dutch, studies have addressed the phenomenon of overeducation and have given many reasons for it. These reasons are e.g. the relatively low burden to enter higher education, job competition and strong screening by employers, which induces investment in skills above the equilibrium levels demanded (e.g. Brunello and Medio, 1996). However, recent technical change, like the introduction of new ICT's, acts as a competing force and has shifted labour demand towards the skilled. This shift in favour of skilled labour increases the price of skilled labour and hence may result in a wage premium for skilled workers. This line of reasoning has been developed by scholars such as Krueger (1993), Autor, Katz and Krueger (1998) and Katz (1999) for the United States. Evidence for the United Kingdom has been brought together by Machin (1996), Green (1999), Haskel and Heden (1999) and Riley and Young (1999). Evidence on other countries is less-developed up to this point in time. ${ }^{11}$ This might be due to the fact that the premium for skilled labour did

\footnotetext{
${ }^{10}$ The analysis and econometric application of Teulings (1995) and Teulings and Vieira (1999) is far more complex. Teulings (1998) examines such an analysis in detail. Here a simple strategy is applied. However, the conclusions which can be drawn from the analysis here are not significantly different from the results obtained in the above mentioned studies. Gautier (2000) also considers the assignment of workers to jobs. He investigates the consequences for both skilled and unskilled employment rates when unemployed skilled workers search for both simple and complex jobs and continue search for complex jobs when they are assigned to a simple job first. Van den Berg, Gautier, Van Ours and Ridder (1999) investigate whether cyclical crowding out is present in the Netherlands. Taking into account job complexity it turns out that workers with more years of education ar not more productive than their less educated colleagues. They find evidence that workers with relatively many years of schooling select themselves into high wage firms, which is in line with the view of job competition and screening among employers.

${ }^{11}$ There is some evidence on France (Entorf and Kramarz, 1997, Goux and Maurin, 1997 and Entorf, Gollac and Kramarz, 1999) and Germany (DiNardo and Pischke, 1997 and Kaiser, 1998). Groot and De Grip (1991) consider changing demand for skills in the Dutch banking sector. In a book edited by Freeman and Katz (1995) and an OECD (1996) study evidence on some other countries is discussed as well.
} 
not increase to the extent it did in the United States, as is already clear from Figure 2 and 3.

To investigate the Dutch situation Teulings (1995) introduces the concept of job complexity, which is to a certain extent similar to Rosen's (1974) model where heterogenous and utility maximizing workers choose the optimal amount of job complexity.

Such complexity can be measured by the degree of heterogeneity among jobs and the extent of substitution between different worker levels. The heterogeneity is determined by the tasks and skills required to perform such a job. For example, a secretary might have some similar skills as a manager but the extent of substitution might be very limited because the secretary misses some essential high-level skills to be a manager. However, a manager is often fully able to perform the tasks of a secretary. On the other hand, the extent of substitution between a secretary and a clerk might be very high because their skills are not so different. Consequently, the lower the level of job complexity the more substitution between workers is possible.

Job complexity also plays a role in the distinction between worker types (e.g. blue versus white-collar workers). Gould (1997) argues in this respect that the skills that determine a worker's ability as a doctor are very different from those that are used as a factory worker. As a consequence, those who are good at being a doctor may not be very productive factory workers and vice versa. Substituting a professor of chemistry with a professor of economics may turn out to be a disaster. Hence, the extent of substitution between different types of workers is very limited. This limited substitution leads to distinct 'occupational cells', and explains a part of the current boom in wages of some occupations such as software programmers and other ICTrelated workers.

To analyse labour demand and supply empirically consider the predicted values of the regression in Panel A of Table 1 as a measure of a worker's skill. This is a plausible assumption, since the set of personal characteristics is a reflection of a worker's capabilities standard to the literature. Similarly, consider the linear combination of job characteristics in Panel B of Table 1 as a measure of the 
complexity of the job. This is in line with the extent of substitution between job levels and types discussed above. The predicted values in Panel $\mathrm{C}$ of Table 1 can be viewed as a measure of 'within' or 'between' sector changes in the assignment of workers to jobs, i.e. 'upgrading' (e.g. Berman, Bound and Machin, 1998 and Haskel and Slaughter, 1998). In this regard, within changes are defined as changes in the wagebill share of particular workers within a sector. Between changes reflect the fact whether a change in the composition of the workforce is similar between different sectors in the economy. ${ }^{12}$

Panel A of Table 2 first shows the correlation between the measure of skill and complexity. The correlation coefficients are at first rather low but steadily increasing over time. This suggests that over time higher skilled workers have been assigned to more complex jobs and that this is increasing over the sample period. This is an interesting observation because it suggests that over time the assignment of workers to jobs has become more efficient. This more efficient assignment of workers to jobs might be the result of technical change which is in line with the move from point $\mathrm{B}$ to $\mathrm{C}$ in Figure 1.

Panel A also contains the same information on the correlation of a worker's skill and the sector of employment. This second correlation shows a relation between skills and upgrading. This measure is clearly not as strong as the first correlation because the causal relation between skill and sector might be subject to many other effects. However, the correlation coefficients do point towards increasing between sector 'upgrading' (higher correlation coefficients), which induces higher log hourly

\footnotetext{
${ }^{12}$ Machin and Van Reenen (1998) define the aggregate change in the skilled proportion over a given time period $\Delta P$ as

$$
\Delta P=\sum_{i} \Delta S_{i} \bar{P}_{i}+\sum_{i} \Delta P_{i} \bar{S}_{i}
$$

where $P_{i}$ is the proportion of skilled workers in industry $i$ and $S_{i}$ is the share of total employment in industry $i$. A bar over a variable denotes a time mean. The first term on the right-hand side is the change in the aggregate proportion of skilled workers attributable to shifts 'between' industries with different proportions of skilled workers. The second term in the expression is the change attributable to changes in the proportion of skilled workers 'within' industries.
} 
wages. This suggests that although sectors are not moving similarly from point $\mathrm{B}$ to $\mathrm{C}$ in Figure 1, they are moving more in line with each other in 1998 than in 1986.

Finally, Panel A analyses the correlation of the predicted values of job complexity and sector upgrading. This steadily rising correlation coefficient gives insight as to which sectors pay a higher wage to similar jobs relative to other sectors. The correlation coefficient is rather low suggesting that jobs of similar complexity in different sectors are not valued similarly. This is in line with the findings of Berman, Bound and Machin (1998) for several OECD countries that the bulk of the change in the prices for skills is going on within, rather than between, sectors. This leads to different valuations for similar job complexity levels between sectors, and underlines the fact that workers are "trapped" in a particular occupational cell as argued above.

In Panel B, the values of all three measures for 1986-98 are reconsidered, weighing personal, job and sector characteristics with their coefficients for 1986. In this manner, it is possible to compare the values of the skill and job complexity and sector upgrading for all seven years. From Panel B it can be observed that, comparing 1986 with 1998, the mean of the skill measure rose by 16.4 percent (from 2.244 to 2.408), the mean of the measure of job complexity rose, in a comparable manner, by 16.6 percent (from 2.293 to 2.459 ) and the mean of the measure of sector upgrading rose by only 10.3 percent (from 2.331 to 2.434 ).

The first two observations indicate that the increase in the average level of job complexity as a result of increasing skills demand is captured by the rise in the supply of skilled workers. However, the complexity of the sectoral component is not catching up with the rise in both demand and supply. These results give an explanation why wages have not gone up dramatically in the Netherlands. If the increased demand for skills as a result of technical change has been captured by the (over)supply of skills there is no need for employers to pay wages above the initial level in Figure 1. The reason for this almost perfect adjustment might reflect a more efficient assignment of workers to jobs since 1980's. This is also supported by the results from Panel A, which indicate a more efficient assignment of workers to jobs over the period 1986-98. However, these results run counter to the results of studies that predict an increase in overeducation in the 1990's in the Netherlands. If 
overeducation would have increased the increase in the coefficient of skill would have increased more than the measure of job complexity.

Finally, in Panel C of Table 2, the measures from Panel B of job complexity and sector upgrading are regressed on the measures of skill. First, this is done separately. It can be observed that the effect of an additional unit of skill on the expected complexity of the job is significantly higher in 1998 than in 1986. The results with regard to sector upgrading point into the same direction but are less severe. In general the coefficient remains constant with some peaks in 1988 and 1994. Second, combining both job complexity and sector upgrading it is possible to explain most of the effects of an additional unit of skill on the expected overall complexity. Again the coefficient is rising over time.

In terms of the predictions of the model by Teulings (1995) this yields - when the job complexity is a function of skill - that the distribution of the skill function in terms of complexity has narrowed, which runs counter to the empirical results obtained by Teulings. He finds that the effects of an additional unit of skill on the expected complexity of the job a worker performs is less in 1988 than in 1982. The main reason given for this was that "the large supply of highly skilled workers makes it less likely that they will obtain highly complex jobs in 1988 than was previously the case" (p. 285). This suggests that the findings by Teulings (1995) and many other for the Netherlands for the 1980's do not apply to the 1990's and that technical change has indeed increased job complexity throughout the 1990's, thereby increasing the returns to education and assigning workers more efficiently.

These observations point towards a move from point $\mathrm{B}$ tot point $\mathrm{C}$ in Figure 1 because the effect of an additional unit of skill and sector upgrading on the expected complexity of the job is significantly higher in 1998 than in 1986. This indicates that following the large increase in supply of skilled workers, demand is adjusting and hence the returns to skill are increasing. This is exactly what is captured by the move from the short-run to the long-run equilibrium in Figure 1.

[INSERT TABLE 2 OVER HERE] 


\section{Concluding Remarks}

This approach has offered a link between the return to skill and the assignment of workers to jobs, which yielded predictions for the return to skill, the allocation of workers to jobs, and te distribution of wages. The paper also offered an explanation of the relative stable wage structure in the Netherlands in the period 1986-98 despite the labour market changes following the introduction of new ICT's in this period. Although the data set is relatively small, the results are statistically strong and significant.

Many studies have established that the introduction of new ICT's has led to a change in the wage structure in favour of high-skilled workers. It is argued that these workers adjust relatively easily and rapidly to the changing work environment. Katz (1999) argues that many labour market analysts have tried to draw a causal connection between rising wage inequality and increases in the growth rate of the relative demand for high-skilled workers driven by technical changes associated with the computer revolution (e.g. Krueger, 1993 and Haskel and Heden, 1999). However, as Freeman and Katz (1995) argue labour demand factors do not explain much of the differential growth of wage inequality or educational earnings differentials.

In contrast, differential growth in the supply of workers by level of education has contributed to the greater rise in educational wage differentials. Most studies imply that improvements in access to post-secondary education and appropriate skills training may be necessary to allow the wage benefits of the new technologies associated with the digital economy to be more widely shared. Murphy, Riddell and Romer (1998) argue that this is particularly true for the United States. Katz and Freeman (1995) add to this that countries with at least modest increases in skill differentials by the end of the 1980's (besides the United Kingdom and the United States also Australia and Japan) experienced some decline in the rate of growth of the supply of skilled workers. Other countries, like the Netherlands, have already established relatively good access to post-secondary education and faced a larger increase in the supply of skilled labour than in the United States. 
Indeed, many studies reveal that in the Netherlands high and persistent levels of overeducation were present from the 1960's onwards. These levels of overeducation may have resulted in a relatively stable wage structure. In terms of Figure 1, the United States might have faced a move from point B to C, while the Netherlands are facing a move from point B' to C'.

This paper has provided evidence in favour of this latter effect. In an empirical manner, wages in the Netherlands are analysed. The results from this exercise are that over time higher skilled workers have been assigned to more complex jobs and that this is increasing over the sample period. This observation suggests that the assignment of workers to jobs has become more efficient which indicates a better "utilisation" of workers. This result is reinforced by the increase in the average level of complexity of labour demand which is similar to the rise in the level of skill among workers.

Together these results provide an explanation why wages have been relatively stable in the Netherlands: the increase in the demand for skills as a result of technical change has been captured by a more efficient assignment of workers to jobs and not by dramatically increasing wages.

In the end, the early observations of Douglas (1926) and Tinbergen (1975) seem to be applicable to the current labour market developments. As a result of good access to education, the Netherlands have absorbed the recent increase in demand for skilled labour relatively easy. 


\section{References}

Acemoglu, K.D. (1999), 'Changes in Unemployment and Wage Inequality: An Alternative Theory and Some Evidence,' American Economic Review, 89, pp.1256-78.

Acemoglu, K.D. (1998), 'Why do New Technologies Complement Skills? Directed Technical Change and Wage Inequality,' Quarterly Journal of Economics, 113, pp. 1055-89.

Allen, S. (1996), 'Technology and the Wage Structure,' National Bureau of Economic Research Working Paper No. 5534.

Autor, D., L.F. Katz and A.B. Krueger (1998), 'Computing Inequality: Have Computers Changed the Labor Market,' Quarterly Journal of Economics, 113, pp. 1169-1213.

van den Berg, G.J., P.A. Gautier, J.C. van Ours and G. Ridder (1999), 'Worker Turnover at the Firm Level and Crowding Out of Lower Educated Workers,' Central Planning Bureau Research Memorandum No. 144.

Berman, E., J. Bound and Z. Griliches (1994), 'Changes in the Demand for Skilled Labor within U.S. Manufacturing Industries,' Quarterly Journal of Economics, 109, pp. 367-98.

Berman, E., J. Bound and S.J. Machin (1998), 'Implications of Skill-Biased Technological Change: International Evidence,' Quarterly Journal of Economics, 113, pp. 1245-79.

Broer, P. and W. Jansen (1989), 'Employment, Schooling and Productivity Growth,' De Economist, 137, pp. 425-53.

Brunello, G. and A. Medio (1996), 'A Job Competition Model of Workplace Training and Education,' Fondazione Eni Enrico Mattei Note di Lavoro Working Paper 75-96.

Card, D., F. Kramarz and T. Lemieux (1999), 'Changes in the Relative Structure of Wages and Employment: A Comparison of the United States, Canada and France,' Canadian Journal of Economics, 32, pp. 843-77.

Chennells, L. and J. Van Reenen (2000), 'The Effects of Technical Change on Skills, Wages and Employment: A Survey of the Micro-Econometric Evidence,' in J. Mairesse and N. Greenan (eds.), The Economic Impact of Information and Communications Technologies, MIT Press, Cambridge MA (forthcoming).

DiNardo J. and J.-S. Pischke (1997), 'The Return to Computer Use Revisited: Have Pencils Changed the Wage Structure Too?' Quarterly Journal of Economics, 112, pp. 291-303.

Douglas, P. (1926), 'What is Happening to the 'White-Collar-Job' Market?' System: the Magazine of Business, December.

Draper, D.A.G. and A.J.G. Manders (1997), 'Structural Change in the Demand for Labour,' De Economist, 145, pp. 521-46.

Entorf, H., M. Gollac and F. Kramarz (1999), 'New Technologies, Wages and Worker Selection,' Journal of Labor Economics, 17, pp. 464-91.

Entorf H. and F. Kramarz (1997), 'Does Unmeasured Ability Explain the Higher 
Wages of New Technology Workers,' European Economic Review, 41, pp. 1489-1509.

Freeman, R.B. (1976), The Overeducated American, Academic Press, New York.

Freeman, R.B. and L.F. Katz (eds.) (1995), Differences and Changes in Wage Structures, University of Chicago Press, Chicago/NBER.

Gautier, P.A. (2000), 'Do More High-Skilled Workers Occupy Simple Jobs during Bad Times,' in: L. Borghans and A. de Grip (eds.), The Overeducated Worker? The Economics of Skill Utilization, Edward Elgar, Cheltenham (forthcoming).

Gottschalk, P. (1997), 'Inequality, Income Growth, and Mobility, The Basic Facts,' Journal of Economic Perspectives, 11, pp. 21-40.

Goldin, C. and L.F. Katz (1998), 'The Origins of Technology-Skill Complementarity,' Quarterly Journal of Economics, 113, pp. 693-732.

Gould, E.D. (1997), 'Rising Wage Inequality, Comparative Advantage, and the Growing Importance of General Skills in the United States: 1966-92,' University of Chicago, mimeo.

Goux, D. and E. Maurin (1997), 'Changes in the Demand for Labour in France,' STI Review, 18, OECD, Paris.

Green, F. (1999), 'The Value of Skills,' University of Kent, mimeo June.

Griliches, Z. (1969), 'Capital-Skill Complementarity,' Review of Economics and Statistics, 51, 465-8.

Groot, L. and A. de Grip (1991), 'Technological Change and Skill Formation in the Bank Sector,' Economics of Education Review, 10, pp. 57-71.

Hartog, J. (1999), 'On Returns to Education: Wandering along the Hills of ORU Land,' in: H. Heijke and J. Muysken (eds.), Education and Training in a Knowledge Based Economy, MacMillan, Basingstoke, pp. 3-45.

Hartog, J. and H. Oosterbeek (1988), 'Education, Allocation and Earnings in the Netherlands: Overschooling?' Economics of Education Review, 7, pp. 185-94.

Hartog, J., H. Oosterbeek and C.N. Teulings (1993), 'Age, Wage and Education in the Netherlands,' in: P. Johnson and K.F. Zimmerman (eds.), Labour Markets in an Aging Europe, Cambridge University Press, Cambridge.

Haskel, J. and Y. Heden (1999), 'Computers and the Demand for Skilled Labour: Industry- and Establishment-Level Panel Evidence for the UK,'Economic Journal, 109, pp. C68-C79.

Haskel, J. and Slaughter (1998), 'Does the Sector Bias of Skill-Biased Technical Change Explain Changing Wage Inequality?,' National Bureau of Economic Research Working Paper 6565.

Hebbink, G. (1991), 'Employment by Level of Education and Production Factor Substitutability,' De Economist, 139, pp. 379-99.

Juhn, C., K.M. Murphy and B. Pierce (1993), 'Wage Inequality and the Rise in Returns to Skill,' Journal of Political Economy, 101, pp. 410-42.

Kaiser, U. (1998), 'The Impact of New Technologies on the Demand for Heterogenous Labour,' Zentrum für Europäische Wirtschaftsforschung, mimeo. 
Katz, L.F. (1999), 'Technological Change, Computerization and the Wage Structure,' Paper presented at the conference on "Understanding the Digital Economy: Data, Tools and Research," Washington DC, May 25-26.

Katz, L.F. and R.B. Freeman (1995), 'Introduction and Summary,' in: R.B. Freeman and L.F. Katz (eds.), Differences and Changes in Wage Structures, University of Chicago Press, Chicago/NBER, pp. 1-22.

Katz, L.F., G.W. Loveman and D.G. Blanchflower (1995), 'Changes in the Structure of Wages in Four OECD Countries,' in: R.B. Freeman and L.F. Katz (eds.), Differences and Changes in Wage Structures, University of Chicago Press, Chicago/NBER, pp. 25-66.

Katz, L.F. and K.M. Murphy (1992), 'Changes in Relative Wages, 1963-87: Supply and Demand Factors,' Quarterly Journal of Economics, 107, pp. 35-78.

Kiley, M. (1999), 'The Supply of Skilled Labour and Skill-Biased Technological Progress,' Economic Journal, 109, pp. 708-24.

Krueger, A.B. (1993), 'How Computers Have Changed the Wage Structure: Evidence from Micro Data 1984-1989,' Quarterly Journal of Economics, 108, pp. 33-60.

Krusell, P., L.E. Ohanian, J.-V. Ríos-Rull and G.L. Violante (1997), 'Capital Skill Complementarity and Inequality: A Macroeconomic Analysis,' Federal Reserve Bank of Minneapolis, Staff Report 239 (forthcoming Econometrica).

Layard, R., S.J. Nickell and R. Jackman (1991), Unemployment: Macroeconomic Performance and the Labour Market, Oxford University Press, Oxford.

Lloyd-Ellis, H. (1999), 'Endogenous Technological Change and Wage Inequality,' American Economic Review, 89, pp. 47-77.

Machin, S.J. (1996), 'Changes in the Relative Demand for Skills,' in: A. Booth and D.J. Snower (eds.), Acquiring Skills, Cambridge University Press, New York, pp. 129-46.

Machin, S.J. and J. Van Reenen (1998), 'Technology and Changes in Skill Structure: Evidence from Seven OECD Countries,' Quarterly Journal of Economics, 113, pp. 1215-44.

Murphy, K.M., W.C. Riddell and P.M. Romer (1998), 'Wages, Skills and Technology in the United States and Canada,' in: E. Helpman (ed.), General Purpose Technologies and Economic Growth, MIT Press, Cambridge MA, pp. 283309.

Murphy, K.M. and F. Welch (1999), 'Wage Inequality in the 1990s,' Paper presented at the Annual Meeting of the American Economic Association, New York, January.

OECD (1996), Technology, Productivity and Job Creation, OECD, Paris.

Oosterbeek, H. (1990), 'Education and Earnings in the Netherlands: An Empirical Analysis,' European Economic Review, 34, 1353-75.

Oosterbeek, H. and D. Webbink (1997), 'Is there a Hidden Technical Potential,' De Economist, 145, pp. 159-77.

Riley, R. and G. Young (1999), 'The Skill Bias of Technological Change in the UK,' Paper presented at the European Association of Labour Economists, 
Regensburg, Germany, September.

Rosen, S. (1974), 'Hedonic Prices and Implicit Markets: Product Differentiation in Pure Competition,' Journal of Political Economy, 82, pp. 34-55.

Rumberger, R. (1981), Overeducation in the U.S. Labor Market, Praeger Publishers, New York.

Sanders, M.W.J.L. and B.J. ter Weel (1999), 'Skill-Biased Technical Change: Theoretical Concepts, Empirical Problems and a Survey of the Evidence,' Maastricht Economic Research Institute on Innovation and Technology, mimeo 1 December.

Sicherman, N. (1991), 'Overeducation in the Labor Market,' Journal of Labor Economics, 9, pp. 101-22.

Teulings, C.N. (1995), 'The Wage Distribution in a Model of the Assignment of Skills to Jobs,' Journal of Political Economy, 103, pp. 280-315.

Teulings, C.N. (1998), 'Aggregation Bias in Elasticities of Substitution and the Minimum Wage Paradox,' Tinbergen Institute Discussion Paper 98-118/3 (forthcoming International Economic Review).

Teulings, C.N. and J.A.C. Vieira (1999), 'Urban versus Rural Return to Human Capital in Portugal: A Cook-Book Recipe for Applying Assignment Models,' Tinbergen Institute, mimeo.

Tinbergen, J. (1975), Income Differences: Recent Research, North-Holland, Amsterdam.

van der Wiel, H.P. (1999), 'Loondifferentiatie in Nederland na 1969; Een Sectorale Invalshoek,' Central Planning Bureau Research Memorandum No. 154. 


\section{Figure 1}

\section{Increasing Supply of Skilled Labour, Technical Change and the Resulting Skill Premium}

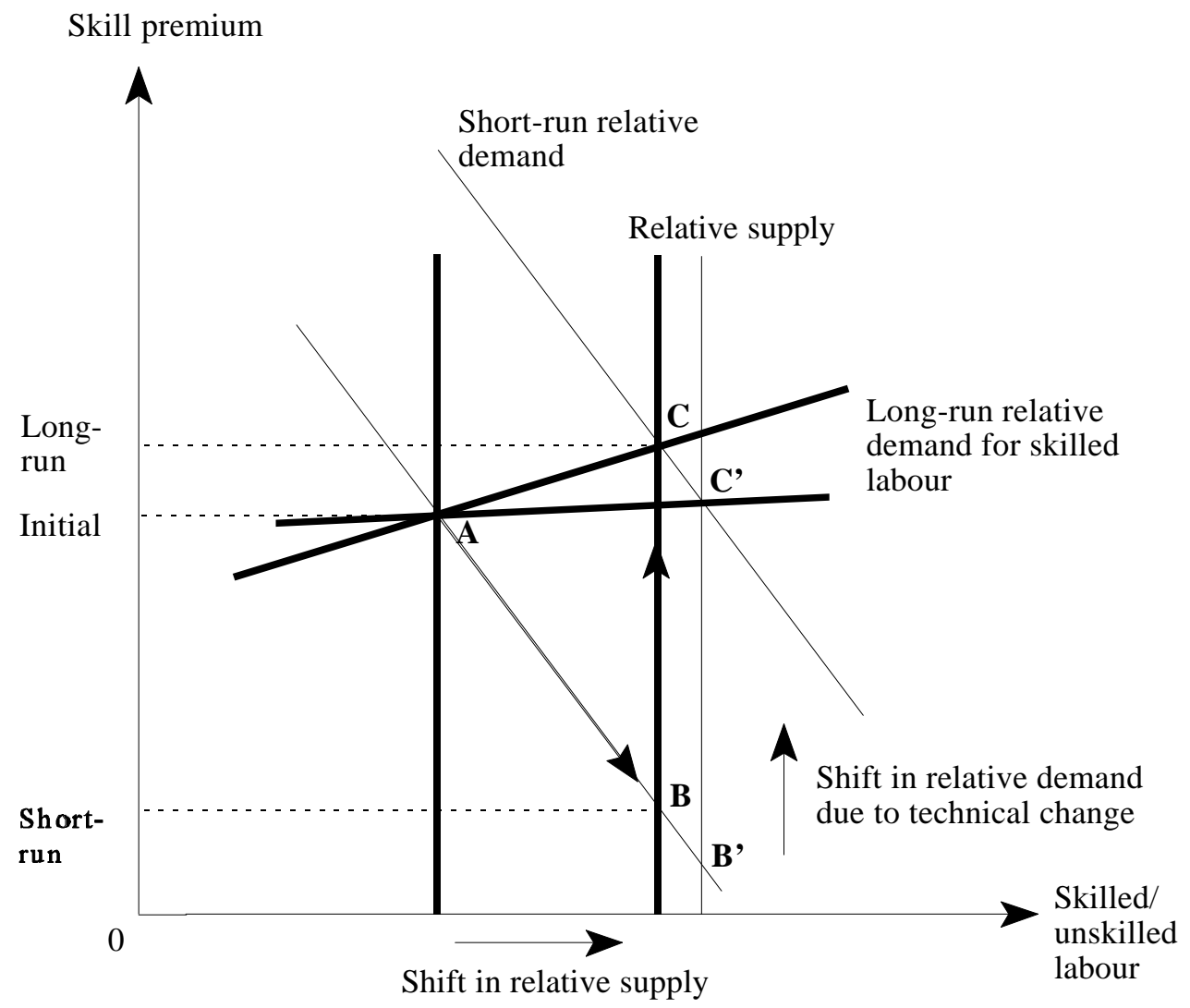

Source: Adapted from Acemoglu (1998), p. 1057 


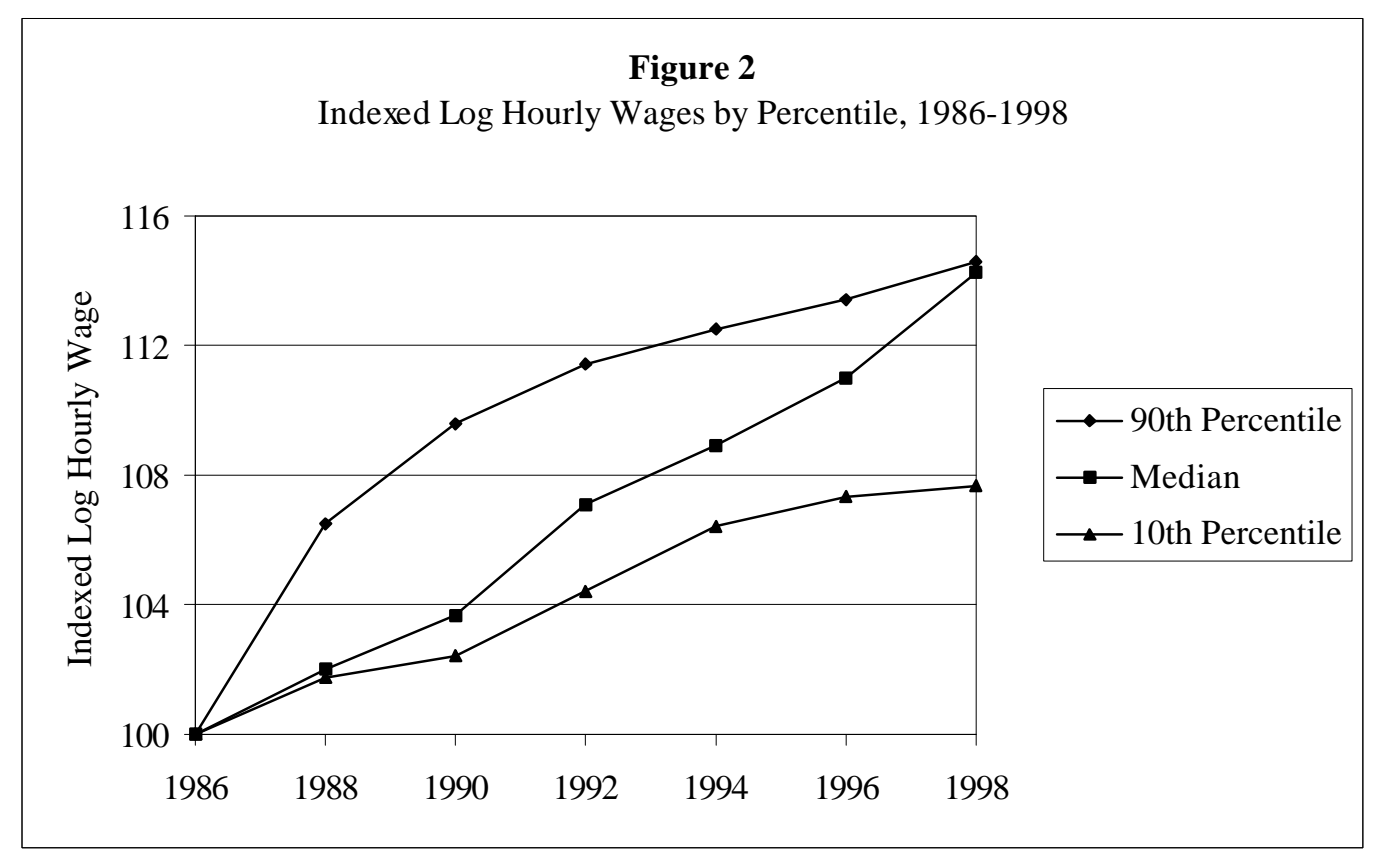




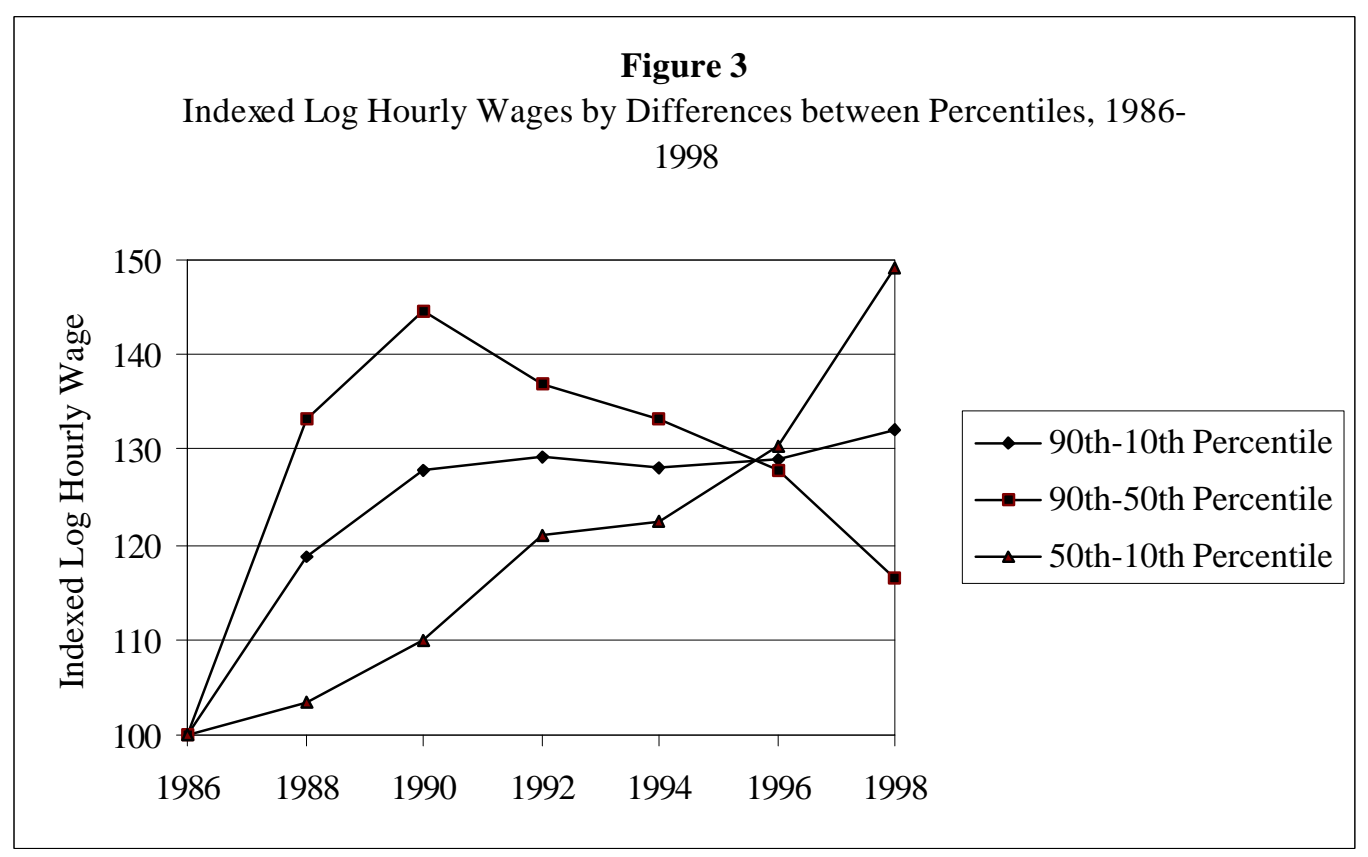


TABle 1 - Regression of Log Hourly Wages on Personal, Job AND Sector CHARACTERISTiCs

\begin{tabular}{|c|c|c|c|c|c|c|c|c|}
\hline & $\begin{array}{l}\text { Total sample } \\
(N=17,436)\end{array}$ & $\begin{array}{c}1986 \\
(N=2,325)\end{array}$ & $\begin{array}{c}1988 \\
(N=2,279)\end{array}$ & $\begin{array}{c}1990 \\
(N=2,352)\end{array}$ & $\begin{array}{c}1992 \\
(N=2,399)\end{array}$ & $\begin{array}{c}1994 \\
(N=2,531)\end{array}$ & $\begin{array}{c}1996 \\
(N=2,654)\end{array}$ & $\begin{array}{c}1998 \\
(N=2,896)\end{array}$ \\
\hline \multicolumn{9}{|c|}{ A. Personal Characteristics Only } \\
\hline Intercept & $.426(.048)$ & $.355(.158)$ & $.022(.133)$ & $.383(.131)$ & $.806(.129)$ & $.463(.101)$ & $.432(.092)$ & $603(.099)$ \\
\hline Age & $.069(.002)$ & $.068(.008)$ & $.075(.007)$ & $.075(.007)$ & $.052(.007)$ & $.058(.005)$ & $.070(.005)$ & $.059(.005)$ \\
\hline $\mathrm{Age}^{2} / 100$ & $-.001(.000)$ & $-.001(.000)$ & $-.001(.000)$ & $-.001(.000)$ & $-.001(.000)$ & $-.001(.000)$ & $-.001(.000)$ & $-.001(.000)$ \\
\hline Non-Dutch & $-.008(.020)$ & $-.062(.053)$ & $-.083(.049)$ & $.057(.055)$ & $.055(.053)$ & $.089(.062)$ & $.037(.036)$ & $-.006(.038)$ \\
\hline Female & $-.069(.008)$ & & & $-.142(.021)$ & $-.159(.020)$ & $-.165(.014)$ & $-.173(.014)$ & $-.172(.014)$ \\
\hline Married & $.023(.009)$ & $.041(.027)$ & $.009(.026)$ & $.004(.026)$ & $.042(.025)$ & $.064(.018)$ & $.062(.017)$ & $.048(.017)$ \\
\hline Level of education & $.042(.001)$ & $.029(.004)$ & $.051(.004)$ & $.040(.004)$ & $.046(.004)$ & $.056(.003)$ & $.047(.003)$ & $.053(.003)$ \\
\hline $\mathrm{R}^{2}$ adjusted & .325 & .371 & .319 & .295 & .279 & .499 & .452 & .426 \\
\hline \multicolumn{9}{|c|}{ B. Job Characteristics Only } \\
\hline Intercept & $2.367(.011)$ & $2.133(.020)$ & $2.237(.033)$ & $2.334(.032)$ & $2.427(.029)$ & $2.423(.025)$ & $2.473(.023)$ & $2.574(.025)$ \\
\hline \multicolumn{9}{|l|}{ Job (reference: low blue-collar): } \\
\hline 0 (elementary) & $.080(.013)$ & $.078(.035)$ & $.077(.031)$ & $.069(.038)$ & $.056(.039)$ & $-.089(.033)$ & $-.110(.032)$ & $-.096(.035)$ \\
\hline 1 (low white-collar) & $.054(.013)$ & $.102(.027)$ & $.091(.045)$ & $.018(.041)$ & $-.025(.038)$ & $.003(0.27)$ & $-.096(.026)$ & $-.062(.028)$ \\
\hline 2 (medium blue-collar) & $.168(.011)$ & $.174(.021)$ & $.164(.037)$ & $.174(.033)$ & $.174(.031)$ & $.101(.026)$ & $.054(.025)$ & $.081(.026)$ \\
\hline 2 (medium white-collar) & $.174(.011)$ & $.211(.023)$ & $.145(.036)$ & $.127(.034)$ & $.105(.031)$ & $.132(.025)$ & $.073(.023)$ & $.086(.025)$ \\
\hline 3 (high blue-collar) & $.445(.014)$ & $.497(.029)$ & $.468(.042)$ & $.377(.041)$ & $.425(.037)$ & $.442(.031)$ & $.304(.029)$ & $.306(.029)$ \\
\hline 3 (high white-collar) & $.396(.014)$ & $.387(.033)$ & $.385(.047)$ & $.377(.042)$ & $.299(.038)$ & $.322(.033)$ & $.307(.029)$ & $.283(.030)$ \\
\hline 4 (scientific blue-collar) & $.501(.025)$ & $.469(.051)$ & $.475(.077)$ & $.414(.076)$ & $.476(.073)$ & $.573(.052)$ & $.400(.048)$ & $.401(.052)$ \\
\hline 4 (scientific white-collar) & $.553(.022)$ & $.500(.057)$ & $.547(.074)$ & $.513(.071)$ & $.489(.065)$ & $.520(.047)$ & $.451(.040)$ & $.345(.041)$ \\
\hline Log firm size & $.020(.002)$ & $.017(.003)$ & $.016(.006)$ & $.021(.006)$ & $.023(.005)$ & $.028(.004)$ & $.041(.004)$ & $.039(.004)$ \\
\hline Log number supervised & $.063(.003)$ & $.068(.007)$ & $.071(.009)$ & $.070(.010)$ & $.071(.009)$ & $.058(.007)$ & $.060(.006)$ & $.055(.007)$ \\
\hline $\mathrm{R}^{2}$ adjusted & .269 & .356 & .220 & .213 & .244 & .416 & .363 & .326 \\
\hline
\end{tabular}


TABle 1 - Regression of Log Hourly Wages on Personal, Job AND Sector CHARACTERISTiCs

\begin{tabular}{|c|c|c|c|c|c|c|c|c|}
\hline & $\begin{array}{l}\text { Total sample } \\
(N=17,436)\end{array}$ & $\begin{array}{c}1986 \\
(N=2,325)\end{array}$ & $\begin{array}{c}1988 \\
(N=2,279)\end{array}$ & $\begin{array}{c}1990 \\
(N=2,352)\end{array}$ & $\begin{array}{c}1992 \\
(N=2,399)\end{array}$ & $\begin{array}{c}1994 \\
(N=2,531)\end{array}$ & $\begin{array}{c}1996 \\
(N=2,654)\end{array}$ & $\begin{array}{c}1998 \\
(N=2,896)\end{array}$ \\
\hline \multicolumn{9}{|c|}{ C. Sector Characteristics Only } \\
\hline Intercept & $2.762(.012)$ & $2.487(.031)$ & $2.519(.041)$ & $2.658(.041)$ & $2.738(.040)$ & $2.702(.034)$ & $2.757(.030)$ & $2.923(.015)$ \\
\hline $\begin{array}{l}\text { Sector (reference: transport): } \\
1 \text { (agriculture) } \\
2 \text { (food, beverages etc.) } \\
3 \text { (other industry) } \\
4 \text { (chemicals) } \\
5 \text { (metal products) } \\
6 \text { (energy) } \\
7 \text { (construction) } \\
8 \text { (trade) } \\
9 \text { (other services) } \\
10 \text { (banks) } \\
11 \text { (non-profit services) } \\
12 \text { (government) }\end{array}$ & $\begin{array}{r}-.086(.026) \\
-.136(.028) \\
-.194(.020) \\
-.047(.033) \\
-.120(.019) \\
.039(.030) \\
-.162(.019) \\
-.236(.016) \\
-.140(.016) \\
-.002(.022) \\
-.133(.015) \\
.091(.015)\end{array}$ & $\begin{array}{r}-.185(.079) \\
-.155(.065) \\
-.121(.047) \\
-.092(.089) \\
-.081(.042) \\
.003(.072) \\
-.049(.043) \\
-.198(.038) \\
-.130(.039) \\
-.017(.050) \\
-.129(.037) \\
.109(.036)\end{array}$ & $\begin{array}{r}-.114(.119) \\
.006(.082) \\
-.062(.061) \\
-.002(.110) \\
.058(.057) \\
.224(.085) \\
-.046(.058) \\
-.070(.053) \\
-.009(.050) \\
.143(.069) \\
-.022(.049) \\
.227(.049)\end{array}$ & $\begin{array}{r}-.257(.105) \\
-.019(.077) \\
-.142(.059) \\
.056(.089) \\
-.016(.057) \\
.040(.086) \\
-.094(.057) \\
-.141(.051) \\
-.063(.050) \\
.115(.069) \\
-.099(.049) \\
.166(.050)\end{array}$ & $\begin{array}{r}-.228(.094) \\
-.077(.074) \\
-.101(.059) \\
.112(.084) \\
.052(.056) \\
.111(.079) \\
-.077(.055) \\
-.163(.048) \\
-.061(.047) \\
.057(.063) \\
-.065(.047) \\
.165(.047)\end{array}$ & $\begin{array}{r}-.140(.090) \\
-.020(.062) \\
-.066(.050) \\
.045(.070) \\
-.008(.048) \\
.243(.075) \\
-.084(.049) \\
-.130(.041) \\
-.019(.041) \\
.094(.060) \\
-.060(.039) \\
.239(.040)\end{array}$ & $\begin{array}{r}-.111(.062) \\
-.018(.065) \\
-.062(.047) \\
.065(.064) \\
-.012(.043) \\
.294(.070) \\
-.082(.043) \\
-.143(.037) \\
-.015(.037) \\
.117(.050) \\
-.008(.035) \\
.207(.036)\end{array}$ & $\begin{array}{r}-.093(.030) \\
.000(.000) \\
-.138(.053) \\
.010(.005) \\
-.089(.079) \\
-.079(.068) \\
-.074(.041) \\
-.281(.028) \\
-.148(.031) \\
.043(.046) \\
-.101(.024) \\
.173(.030)\end{array}$ \\
\hline $\mathrm{R}^{2}$ adjusted & .144 & .162 & .132 & .131 & .135 & .192 & .166 & .174 \\
\hline
\end{tabular}

Notes: Estimates by OLS with dependent variable the logarithm of hourly wages of employees. Standard errors in Brackets. The coefficient for level of education reflects the return to an additional year of education. In 1986 and 1988 the data contain only males. 
TABLE 2 - SKILLS, COMPLEXITIES AND UPGRADING

\begin{tabular}{|c|c|c|c|c|c|c|c|c|}
\hline & $\begin{array}{l}\text { Total sample } \\
(N=17,436)\end{array}$ & $\begin{array}{c}1986 \\
(N=2,325)\end{array}$ & $\begin{array}{c}1988 \\
(N=2,279)\end{array}$ & $\begin{array}{c}1990 \\
(N=2,352)\end{array}$ & $\begin{array}{c}1992 \\
(N=2,399)\end{array}$ & $\begin{array}{c}1994 \\
(N=2,531)\end{array}$ & $\begin{array}{c}1996 \\
(N=2,654)\end{array}$ & $\begin{array}{c}1998 \\
(N=2,896)\end{array}$ \\
\hline \multicolumn{9}{|c|}{ A. Correlation between Personal, Job and Sector Characteristics } \\
\hline $\begin{array}{l}\text { Correlation explained Panel A and } \\
\text { B of Table } 1\end{array}$ & .410 & .254 & .323 & .490 & .495 & .526 & .526 & .485 \\
\hline $\begin{array}{l}\text { Correlation explained Panel A and } \\
\text { C of Table } 1\end{array}$ & .169 & .104 & .169 & .150 & .189 & .255 & .231 & .231 \\
\hline $\begin{array}{l}\text { Correlation explained Panel B and } \\
\text { C of Table } 1\end{array}$ & .264 & .238 & .273 & .265 & .301 & .362 & .340 & .314 \\
\hline \multicolumn{9}{|c|}{$\begin{array}{c}\text { B. Personal, Job and Sector Characteristics } \\
\text { Weighted with Coefficient for } 1986\end{array}$} \\
\hline \multicolumn{9}{|l|}{ Mean value ( $1^{\text {st }}$ moment $)$ : } \\
\hline Personal characteristics & 2.373 & 2.244 & 2.351 & 2.343 & 2.364 & 2.371 & 2.373 & 2.408 \\
\hline Job characteristics & 2.421 & 2.293 & 2.368 & 2.432 & 2.439 & 2.439 & 2.448 & 2.459 \\
\hline Sector characteristics & 2.431 & 2.331 & 2.425 & 2.434 & 2.434 & 2.434 & 2.431 & 2.434 \\
\hline \multicolumn{9}{|l|}{ Standard deviation ( $2^{\text {nd }}$ moment $)$ : } \\
\hline Personal characteristics & .118 & .182 & .187 & .200 & .190 & .182 & .184 & .176 \\
\hline Job characteristics & .198 & .180 & .177 & .204 & .205 & .202 & .203 & .208 \\
\hline Sector characteristics & .085 & .080 & .080 & .086 & .088 & .089 & .091 & .087 \\
\hline
\end{tabular}


TABLE 2 - SKILLS, COMPLEXITIES AND UPGRADING

\begin{tabular}{|c|c|c|c|c|c|c|c|c|}
\hline & $\begin{array}{l}\text { Total sample } \\
(N=17,436)\end{array}$ & $\begin{array}{c}1986 \\
(N=2,325)\end{array}$ & $\begin{array}{c}1988 \\
(N=2,279)\end{array}$ & $\begin{array}{c}1990 \\
(N=2,352)\end{array}$ & $\begin{array}{c}1992 \\
(N=2,399)\end{array}$ & $\begin{array}{c}1994 \\
(N=2,531)\end{array}$ & $\begin{array}{c}1996 \\
(N=2,654)\end{array}$ & $\begin{array}{c}1998 \\
(N=2,896)\end{array}$ \\
\hline \multicolumn{9}{|c|}{$\begin{array}{l}\text { C. Job Characteristics (Deviation from } 1986 \text { Mean Value) Explained by Personal and by Sector } \\
\text { (Deviation from } 1986 \text { Mean Value) Characteristics }\end{array}$} \\
\hline Intercept & $.058(.001)$ & $-.000(.001)$ & $.001(.003)$ & $.088(.004)$ & $.085(.004)$ & $.076(.004)$ & $.085(.004)$ & $.081(.003)$ \\
\hline Personal Characteristics & $.374(.006)$ & $.240(.020)$ & $.270(.014)$ & $.423(.016)$ & $.432(.017)$ & $.420(.017)$ & $.402(.017)$ & $.428(.018)$ \\
\hline Intercept & $.047(.001)$ & $.000(.002)$ & $.001(.003)$ & $.053(.004)$ & $.061(.004)$ & $.059(.004)$ & $.068(.004)$ & $.074(.004)$ \\
\hline Sector Characteristics & $.589(.014)$ & $.506(.049)$ & $.627(.032)$ & $.543(.039)$ & $.548(.038)$ & $.581(.036)$ & $.563(.035)$ & $.527(.037)$ \\
\hline Intercept & $.068(.001)$ & $.000(.004)$ & $.020(.003)$ & $.093(.004)$ & $.091(.004)$ & $.082(.004)$ & $.091(.004)$ & $.085(.003)$ \\
\hline Personal Characteristics & $.333(.006)$ & $.219(.022)$ & $.238(.013)$ & $.392(.016)$ & $.395(.017)$ & $.372(.017)$ & $.356(.017)$ & $.386(.018)$ \\
\hline Sector Characteristics & $.454(.014)$ & $.456(.048)$ & $.551(.031)$ & $.382(.036)$ & $.377(.036)$ & $.412(.034)$ & $.409(.054)$ & $.355(.036)$ \\
\hline
\end{tabular}

Notes: Initial estimates by OLS as in Table 1. 